\title{
DISNEYJEVI ANIMIRANI ANTROPOMORFI
}

\author{
NADA KUJUNDŽıĆ \\ Nezavisna istraživačica, Zagreb
}

Izvorni znanstveni članak

Primljeno: 1. 7. 2020

Prihvaćeno: 9. 9. 2020

DOI: 10.15176/vol57no203

UDK 791.228

79158

\begin{abstract}
Dopadljive antropomorfne životinje zacijelo su jedno od najprepoznatljivijih obilježja animiranih filmova američkog studija Walt Disney. Snjeguljica i sedam patuljaka (1937.), prvi cjelovečernji animirani Disneyjev film, uz naslovne likove uključuje i niz dobroćudnih šumskih životinja koje pomažu junakinji, štiteći je i obavljajući kućanske poslove. S obzirom na golem uspjeh Snjeguljice, motiv životinjskih pomagača iskorišten je i u narednim filmovima, te $s$ vremenom postaje neizostavan dio Disneyjevog repertoara. $\mathrm{U}$ istraživačkom fokusu ovoga rada upravo su životinjski likovi (tj. likovi ne-ljudskih životinja) u dugometražnim animiranim Disneyjevim filmovima. Korpus istraživanja obuhvaća 48 filmova nastalih u razdoblju od 1937. do 2019. godine. Oslanjajući se na kulturnu animalistiku i postojeća interdisciplinarna istraživanja Disneyjeve animirane produkcije (tzv. Disney studies), rad analizira prikaze životinjskih likova, napose njihovu antropomorfizaciju i način na koji je njihov status protagonista/antagonista vizualno kodiran, te odnos ljudskih i životinjskih likova. Rezultati istraživanja upućuju na dominantno antropocentričnu perspektivu analiziranih filmova.
\end{abstract}

Ključne riječi: animirani film, antropomorfnost, kulturna animalistika, Walt Disney Animation Studio, životinje

\section{UVOD}

lako su životinje (točnije, ne-ljudske životinje) prisutne u svim filmskim žanrovima (Burt 2002: 19), čini se da su posebno mjesto pronašle u animiranom filmu, o kojem je, smatra Thomas LaMarre, teško razmišljati "bez da pomislimo na prizore ne-ljudskih životinja koje izvode ludorije, plešu, skakuću..." (2008: 79). Mogući uzroci popularnosti animiranih životinjskih likova su brojni: od pretpostavljene sklonosti djece (kao česte ciljane publike animiranog filma) da se identificiraju s (antropomorfnim) životinjama (Visković 1996: 245), do činjenice da je životinjske likove (u čijim se prikazima u pravilu tolerira, pa i očekuje, manjak realizma) naprosto lakše animirati (LaMarre 2008: 82). Razigrane, nerijetko i raspjevane antropomorfne životinje jedan su od zaštitnih znakova vjerojatno najpoznatijeg 
i najutjecajnijeg studija za animaciju na svijetu, Studija Walt Disney (Walt Disney Animation Studio).

Životinjski likovi (ili barem životinjolika fantastična bića kakva nalazimo u Crnom kotlu ili Planetu s blagom) javljaju se u svim Disneyjevim dugometražnim animiranim filmovima. Tradicija "oživljavanja" narisanih životinja - prema mnogima područje u kojem Disney uvelike nadmašuje konkurenciju (Finch 2011: 233; Maltin 2000: 275) - čini se logičnim korakom za filmski studio koji svoj postanak duguje uspjehu antropomorfnog miša i njegove družine. Kao "univerzalno najprepoznatljiviji i najomiljeniji lik iz crtića u povijesti" (Holliss i Sibley 1986: 6), Mickey Mouse prvi je u nizu antropomorfa koji će postati neizbježnim djelom "ansambla" Disneyjevih animiranih filmova, od Snjeguljice i sedam patuljaka (1937.), Studijevog dugometražnog animiranog prvijenca, do danas.

Oslanjajući se na bogatu znanstvenu produkciju koja Disneyjeve filmove i druge sadržaje Studija (a šire i Korporacije) Walt Disney kritički razmatra iz raznolikih (mahom kulturnostudijskih) disciplinarnih gledišta (tzv. Disney studies), rad analizira životinjske likove u dugometražnim animiranim filmovima Studija Walt Disney. U tu svrhu koristi teorijsko-metodološki aparat kulturne animalistike, koja se u nas uglavnom orijentirala na književnu animalistiku (Marjanić i Zaradija Kiš 2007, 2012), pa je u tom smislu ovo istraživanje moguće čitati i kao poticaj razvoju filmske animalistike (vidi npr. Burt 2002; Golež Kaučič 2018; Siegel 2005). U središtu zanimanja su vizualni prikazi i karakterizacija Disneyjevih životinjskih likova, te njihov odnos s ljudskim likovima. Istraživanje prikaza životinja obuhvaća njihovu (ne)realističnost, odnosno antropomorfičnost, pri čemu se posebna pozornost posvećuje načinu na koji je pozitivna/negativna karakterizacija pojedinih likova upisana u odabir vrste kojoj pripadaju, kao i njihov izgled (dizajn). Kod odnosa između ljudskih i životinjskih likova u prvom nas redu zanima definira li se isti kao međuovisnost i ravnopravnost, odnosno, u slučaju da filmovi polaze od pretpostavke o ljudskoj nadređenosti, na koji se način ona manifestira.

Bez ikakvih pretenzija na sveobuhvatnost, rad nastoji ukazati na važnost proučavanja animalističke tematike u globalno uspješnim kulturnim proizvodima kao što su Disneyjevi filmovi (Giroux i Pollock 2010). S obzirom na status Disneyja kao giganta kulturne industrije i svojevrsnog "zaštitnika 'obiteljskih vrijednosti”" (Kashani 2010: 223), te golemu popularnost Disneyjevih animiranih filmova, nužno je kritički sagledati prikaze i poruke koje oni nude (ponajprije dječjoj) publici, kao i utjecaj tih istih prikaza i poruka na način na koji publika percipira (za ovo istraživanje važne) ne-ljudske životinje (usp. Anderson i Henderson 2005).

Korpus istraživanja obuhvaća 48 Disneyjevih animiranih filmova nastalih u razdoblju od 1937. (Snjeguljica i sedam patuljaka) do 2019. godine (Snježno kraljevstvo 2). Animirani filmovi nastali u suradnji s drugim studijima za animaciju (npr. Pixar), filmovi rađeni za

${ }^{1}$ O utjecaju Disneyjevih prikaza na popularnu percepciju životinja između ostalih svjedoči i sintagma "disneyfikacija životinja”, koju Steve Baker koristi kako bi opisao dominaciju trivijaliziranih i stereotipnih (“disneyficiranih") prikaza životinja u popularnoj kulturi kao malih, slatkih, smiješnih stvorenja (2001: 174). 
video/DVD tržište, te animirani filmovi koji nemaju jedinstvenu pripovjednu liniju već su "kolaži" ili "pastiši” (Maltin 2000: 93) manjeg ili većeg broja kraćih filmova, poput Šale i mašte, ne ulaze u naš korpus.

\section{REALIZAM I/ILI ANTROPOMORFIZAM}

$U$ istraživanju odnosa između Disneyjevih princeza i njihovih životinjskih prijatelja, Megan Condis primjećuje da su u najranijim dugometražnim Disneyjevim filmovima poput Snjeguljice i Uspavane ljepotice realistični prikazi rezervirani za ljudske likove (animirane tehnikom rotoskopa), dok su prikazi ne-ljudskih životinja bliski zaigranoj, nerealističnoj animaciji kratkometražnih filmova (2015: 42). Zaokret k realizmu u prikazima životinja (njihova izgleda, ponašanja i okoline) do izražaja dolazi u Bambiju, filmu bez ljudskih likova smještenom u naturalistički ambijent šume. Kako bi što vjernije prikazali životinje i njihov prirodan okoliš, za Disneyjeve animatore organizirani su posebni satovi crtanja i anatomije životinja, kao i posjeti zoološkim vrtovima. Štoviše, minijaturni zoološki vrt sagrađen je u sklopu samog Studija (Grant 1998: 197). Međutim, kako primjećuje Ronald Tobias, radi se o realizmu koji je ponajprije stilski, a ne tematski (2011: 189), što rezultira diskrepancijom između gotovo dokumentarističkih tendencija i naglašenog odmaka od stvarnosti, vidljivog u činjenici da životinje govore i žive u zajednicama nalik ljudskima, govore ljudskim jezikom i prijateljuju s vrstama koje ih u stvarnosti ugrožavaju (npr. sove i zečevi; Finch 2011: 189).

Praksa promatranja i crtanja živih modela (engl. drawing from life; Riffel 2012: 15) nastavlja se i u narednim filmovima, pa su tako, primjerice, pripreme za produkciju Kralja lavova uključivale istraživački put u Afriku i dopremanje divljih životinja u Studio Disney (Smith 1996: 290). Zajedno s njom, nastavlja se i spomenuta diskrepancija, jer dok animatori nastoje "stvoriti četveronožne životinje iz džungle koje izgledaju dovoljno realistično da budu uvjerljive", istovremeno ih humaniziraju prepoznatljivim izrazima lica i pridavanjem ljudskih osobina (Maltin 2000: 302). "Realizam” u prikazima Disneyjevih životinjskih likova u tom smislu podrazumijeva vjernost i ljudskom (antropomorfna ekspresivnost) i životinjskom modelu (anatomski realizam; Riffel 2012: 13).

Bez obzira na razinu realizma prisutnu u njihovim prikazima, Disneyjeve animirane životinje - kao i “dječje književne životinje” koje analizira Marijana Hameršak - nužno su, "makar u tragovima antropomorfne", jer se neizbježno prikazuju iz ljudske perspektive i "definira[ju] kroz ljudske odnose i prakse (imena, rodbinske veze, introspekciju i dr.)" (2015: 31). S obzirom na stupanj njihove antropomorfizacije, ${ }^{2}$ Disneyjeve animirane životinje okvirno je moguće svrstati u sljedeće kategorije:

\footnotetext{
${ }^{2}$ Antropomorfizam se definira kao pridavanje psihičkih osobina čovjeka životinji (Visković 1996: 36), odnosno percipiranje "navika i ponašanja određenih životinja kao produžetak nekih od uloga i dužnosti koje nalazimo u ljudskom društvu” (Sax 2013: 148).
} 
a) "Realistične" životinje: ne govore, a budući da filmovi ne nude njihovu karakterizaciju, ne možemo reći da posjeduju ljudske osobine. Uglavnom se radi o "pozadinskim" ili "ambijentalnim" likovima čija pojava u filmu pridonosi stvaranju (uvjerljivog) filmskog okoliša (npr. antilope, gnuovi i druge afričke životinje u Kralju lavova, cirkuske životinje u Sloniću Dumbu itd.).

b) Umjereni antropomorfizam: životinje koje razumiju ljudski govor, ali same ne govore. Široku paletu osjećaja izražavaju "ljudskim” gestama i mimikom lica (npr. tigar Rajah grli princezu Jasmine [Aladin], rakun Meeko može prekrižiti "ruke" na prsima [Pocahontas] i sl.).

c) Antropomorfi: životinje kojima su dane ljudske sposobnosti i osobine, no koje se kreću i izgledaju kao životinje. Ključan razlikovni kriterij ove kategorije jest sposobnost govora, bez obzira na to koriste li je životinje samo u međusobnoj komunikaciji (u Dami i Skitnici ili 101 dalmatincu psi međusobno komuniciraju ljudskim govorom, no za komunikaciju s ljudima koriste lavež i druge animalne zvukove) ili razgovaraju i s ljudima (papagaj lago u Aladinu).

d) Zoomorfi (čovjek u liku životinje): likovi koji izgledaju kao životinje, ali se kreću, odijevaju, govore i žive kao ljudi. Primjer ovih "ljudi u životinjskom ruhu” nalazimo (među ostalima) u Robinu Hoodu, Mišu velikom detektivu, Spasiocima, Žutoj minuti i Zootropoli.

Životinjama s većim stupnjem antropomorfizacije često su suprotstavljene one "običnije", gotovo u potpunosti lišene ljudskih osobina ("realistične" i umjereno antropomorfne životinje). (Ne)sposobnost govora u tom kontekstu funkcionira kao ključno razlikovno obilježje. Znakovito je da su antropomorfiziranije životinje češće prikazane u pozitivnom svjetlu (npr. kao pratioci/pomagači protagonista), dok su one s manje ljudskih obilježja češće negativno intonirane (pratioci/pomagači antagonista). U filmovima kao što su Bambi (Bambijev suparnik Rollo, lovački psi), Dama i Skitnica (štakor, psi lutalice koji napadaju Damu), Spasioci (krokodili), Spasioci u Australiji (gušterica Joanna, aligatori) ili Dinosaur (velociraptori i karnotauri), jedino "zle" životinje ne govore. Nadalje, likovi s većim stupnjem antropomorfizacije redovito imaju istaknute uloge u filmovima, dok su oni koji ne govore uglavnom "pozadinski" likovi, što je slučaj, primjerice, u Sloniću Dumbu ili Dinosauru (Leventi-Perez 2011: 102). Pozitivna valorizacija i pridavanje veće pozornosti životinjama s više ljudskih osobina ukazuju na dominantno antropocentričnu perspektivu Disneyjevih animiranih filmova, koja daje prednost ljudskom nad životinjskim. Nadalje, kako na temelju njihove analize dječjih filmova i književnosti te uz njih vezanih promocija zaključuju Kate Stewart i Matthew Cole, činjenica da se životinjskim likovima subjektivnost pridaje putem ljudskih obilježja "podržava ideju da su, u konačnici, samo ljudi subjekti" (2009: 463), te da se životinje vrednuju i prizivaju identifikaciju ponajprije na temelju njihove sličnosti čovjeku. Dok je sveprisutnu antropomorfizaciju animiranih životinjskih likova u Disneyjevim filmovima, pa i “dječj[oj] svakodnevic[i], književnosti i kultur[i]” općenito (usp. Hameršak 2015: 31), moguće tumačiti kao pokušaj da se životinje približi dječjoj publici, istraživači poput Davida Whitleyja upozoravaju na moguće štetne učinke tih "slatkih" (disneyficiranih), 
na iskrivljenim predodžbama o životinjama utemeljenih prikaza (2008: 3). Jurij Detela, primjerice, naglašava njihovu ulogu u odvraćanju pozornosti (dječje) publike s negativnih aspekata odnosa prema životinjama, poput (krivo)lova i drugih oblika ubijanja i eksploatacije životinja (1977: 524).

\section{CRNO-BIJELO ŽIVOTINJSKO CARSTVO}

Disneyjevi dugometražni animirani filmovi u manjoj ili većoj mjeri slijede pripovjedni obrazac tradicionalne bajke nastale prema modelu kakav su ponudili Charles Perrault i braća Grimm (usp. Harries 2003: 16). Bez obzira na to radi li se o adaptaciji bajke (Snjeguljica i sedam patuljaka, Mala sirena), mita (Herkul) ili romana (Zvonar crkve Notre Dame), ili pak prenošenju stvarnih događaja na filmsko platno (Pocahontas), krajnji rezultat istraživač bajki (i oštar kritičar Disneyjevih filmova) Jack Zipes opisuje kao bajkovitu kombinaciju romantične komedije sa sretnim završetkom i klasičnog broadwayskog mjuzikla, koja obavezno sadrži junakinju u nevolji, oživljene predmete i/ili antropomorfne životinje, pjesme u kojima likovi otkrivaju svoje želje i snove, te pustolovno-ljubavnu priču (2006: 209). Osim pripovjednog obrasca i tipologije likova, Disney od tradicionalne bajke - najvećim djelom izgrađene na binarnim oprekama kao što su dobro/zlo, mlado/staro ili poznato/strano (Tatar 2003: 71) - preuzima i crno-bijelu karakterizaciju. Čak i prije nego ima priliku promotriti postupke određenog lika, publika može prepoznati radi li se "pozitivcu" ili "negativcu" na temelju njegova izgleda. Boje i tonovi korišteni u prikazima pojedinih životinjskih likova, kao i vrsta kojoj pripadaju u tom su smislu vrlo indikativni.

Na vizualnom planu, životinjske likove nerijetko je moguće prepoznati kao dobre/zle već prema boji i/ili tonovima koji dominiraju u njihovu prikazu. Simbolička crno-bijela karakterizacija tako se često konkretizira uporabom crne i bijele boje, odnosno tamnih i svijetlih tonova, pri čemu bijela s pripadajućim asocijacijama svjetlosti i ovozemaljskog označava "pozitivce", a crna, tradicionalno simbol tame, nesreće i podzemlja, označava "negativce" (usp. Šešo 2007: 261, 273). Tako su, primjerice, bijelim golubicama koje Snjeguljici prave društvo suprotstavljeni crni gavran i lešinari koji prate zlu kraljicu. Pozitivno intonirane životinje redovito su dopadljivije i "slađe", prikazane mekšim linijama i toplijim tonovima, dok u prikazima zlih životinja dominiraju oštrije linije i zagasitiji, mračniji tonovi. Osim toga, kako primjećuje John Grant, negativno intonirane životinje često krase crvene, žute ili zelene oči (1998: 391), te prijeteće karakteristike poput isukanih, oštrih kandži, iskešenih zubi i slično. Kao primjer poslužit će nam Kralj lavova, u kojem naslovnu životinju nalazimo u ulozi protagonista i antagonista. lako su braća, dobri Mufasa i zli Scar sušta su suprotnost, kako na moralnom tako i na vizualnom planu: u prikazu krupnog i mišićavog Mufase dominiraju zemljane boje poput žute i narančasto-smeđe, kao i mekše, zaobljenije linije. Scar je, pak, mršaviji, crne grive, prikazan oštrijim linijama i tamnijim nijansama. Kreće se drugačije od ostalih lavova, a k tomu je i jedini koji ima zelene oči i uvijek isukane kandže. Kao što je ranije istaknuto, zle se životinje nerijetko dade prepoznati i po tome što su u 
manjoj mjeri antropomorfizirane; štoviše, u pojedinim je slučajevima o njima teško govoriti kao o likovima u punom smislu riječi jer djeluju prvenstveno kao utjelovljenje opasnosti, neobuzdane snage i divlje prirode (npr. kit u Pinokiju, lovački psi u Bambiju ili medvjed u Lisici i psu).

lako, kako u rječitoj obrani Disneyjevih filmova, televizijskih serija i tematskih parkova primjećuje Douglas Brode, u Disneyjevom filmskom svijetu svaka životinjska vrsta ima i dobre i loše pripadnike (2005: 203), ${ }^{3}$ neke vrste ipak su "bolje“/“lošije” od drugih. Tako u ulogama "pozitivaca" u pravilu nalazimo neopasne vrste koje su iskustveno bliže čovjeku (kućni ljubimci, domaće i šumske životinje), poput pasa, zečeva, konja i miševa. Nadalje, ove "dobre" životinje (naročito psi) nerijetko su pretjerano idealizirane i prikazane kao savršeni pratitelji bez ikakve mane (što, kako pokazuje istraživanje Marle Anderson i Antonie Henderson (2005), može negativno utjecati na odnos osobe odrasle na takvim idealiziranim prikazima prema stvarnim životinjama). Nasuprot tome, uloge "negativaca" ponajviše se dodjeljuju grabežljivcima i drugim životinjskim vrstama koje izazivaju snažne negativne emocije poput straha ili gađenja (npr. štakor, zmija), odnosno koje su prijetnja čovjeku ili se smatraju zloslutnima. Gmazovi (zmije, krokodili, gušteri), ptice grabljivice i razni predatori poput vukova i velikih mačaka najčešći su Disneyjevi "negativci".

Podjela životinjskih vrsta na dobre i zle osobito je zanimljiva u filmovima poput Robina Hooda, u kojima životinjski likovi "igraju” ljudske uloge. Lukavi naslovni junak zadobiva lik lisice, kojoj je suprotstavljen zli šerif od Nottinghama u vučjem obličju. Što zbog kraljevskog statusa, što zbog nadimka, kralj Rikard Lavljeg Srca u Disneyjevoj verziji postaje lav; njegov brat, princ John također je lav, no, za razliku od Rikarda, on je kukavički mladi lav bez grive, k tomu i razmažen i djetinjast (Grant 1998: 290). Oko Robina Hooda okupljaju se mahom pitome i šumske životinje poput pasa, zečeva, kornjača, miševa i kokoši. Nasuprot tomu, princ John svoje zle planove kuje i sprovodi uz pomoć opasnih, divljih životinja poput zmija, krokodila, lešinara i nosoroga.

Životinjski likovi u Disneyjevim filmovima definiraju se kao dobri/loši ponajprije u odnosu na čovjeka, pri čemu se pozitivni atributi pridaju onima koje su mu slične (antropomorfizacija) i/ili bliske (kućni ljubimci, domaće i šumske životinje itd.). Nadalje, (ljudska) interpretacija prirodnog ponašanja i prehrane pojedinih životinja (naročito grabežljivaca) kao negativnih ili nepoželjnih dovodi do njihove demonizacije i smještanja u uloge "negativaca". Pozitivno/ negativno profiliranje životinjskih likova često se oslanja i na razne stereotipe o životinjama (npr. sova, iako u prirodi grabežljivac, najčešće je pozitivno intonirana i prikazana kao mudri savjetodavac) i njihovim "urođenim" neprijateljstvima (npr. mačke i psi; Byrne i McQuillan 1999: 96). Odmak od te tradicije nalazimo u filmu Zootropola, koji podriva

${ }^{3}$ Brode za primjer uzima mačku, životinju koja je kroz povijest često stigmatizirana, što odražavaju njezini često negativni filmski i književni prikazi. U ponešto pretjeranoj pohvali, Brode tvrdi da je "Disney $i$ samo Disney pokušao promijeniti i umanjiti takve predrasude” (2005: 203, kurziv N. K.), navodeći kao primjer nekoliko kratkih animiranih filmova. lako ne može osporiti postojanje mačjih zlikovaca u Disneyjevu repertoaru, autor ih tumači tek kao "povremene posrtaje" koji predstavljaju “iznimke a ne pravila”, a čiji bi izostanak doveo do "neopravdane romantizacije mačke" (ibid.). 
stereotipe o životinjama kritizirajući na njima zasnovanu diskriminaciju (usp. Beaudine i sur. 2017). Grabežljivci za koje se potajno smatra da ne mogu kontrolirati urođenu agresivnost pokazuju se miroljubivim sugrađanima, dok se za naizgled plahu i sramežljivu ovcu (uz koju se često veže stereotip intelektualne ograničenosti; Vidović Bolt 2007: 414) otkriva da je inteligentan zlikovac odgovoran za sve nevolje u filmu.

\section{ODNOS ČOVJEKA I ŽIVOTINJE}

Općenito uzevši, Disneyjevi dugometražni animirani filmovi promoviraju pozitivan odnos čovjeka prema životinji. Štoviše, odnos prema životinjama i reakcije životinja na pojedini ljudski lik često su sredstvo karakterizacije koje trenutačno otkriva radi li se o "pozitivcu" ili "negativcu". Polazeći od njihove pretpostavljene intuicije, životinje tako "osjećaju" zlobu ili dobrotu ljudskih likova i prepoznaju njihove skrivene namjere. Za razliku od naivne Snjeguljice, šumske životinje u naizgled bezopasnoj starici prepoznaju zlu kraljicu. Na sličan način, pas Max (Mala sirena) osjeća da Vanessi (morskoj vještici u ljudskom obličju) ne treba vjerovati, dok protagonisticu Ariel radosno pozdravlja već pri prvom susretu. Nadalje, Disneyjevi ljudski protagonisti redovito vole životinje i brinu o njima (neki, poput princa Erica u Maloj sireni, riskiraju i vlastite živote kako bi ih spasili), dok ih antagonisti fizički zlostavljaju (Majka Gothel [Vrlo zapetljana priča] i Vanessa [Mala sirena] ih udaraju nogama), eksploatiraju (izrabljivanje magaraca u Pinokiju), a katkad i ubijaju (doktor Facilier [Princeza $i$ žabac], te niz likova krivo/lovaca u filmovima poput Bambija, Spasioca u Australiji i Ljepotice i zvijeri) ili pokušavaju ubiti (Cruella De Vil [101 dalmatinac]). ${ }^{4}$ U samo dva filma u našem korpusu - Tarzanu (eponimski junak ubija leoparda - jedinog grabežljivca u filmu - koji je usmrtio njegove roditelje) i Legendi o medvjedu (smrt životinje posljedica je nerazumijevanja i netolerancije čovjeka te potiče transformaciju ljudskog protagonista) protagonisti su ti koji ubijaju životinje.

Služeći se tipologijom koju predlaže Nikola Visković, mogli bismo ustvrditi da Disneyjevi filmovi promoviraju osjećajan odnos između ljudskih i životinjskih likova (1998: 12-13) prikazujući ih kao prijatelje, sugovornike i međusobne pomagače. Međutim, osjećajnim sponama usprkos, svijet ljudi i životinja u pravilu je strogo razdvojen, a čovjek (u skladu s dominantno antropocentričnom perspektivom analiziranih filmova) redovito nadređen životinji. Kao što će pokazati naredni odlomci, ta nadređenost, koju prepoznaju i prihvaćaju i same životinje, očituje se isticanjem poželjnosti domestikacije, prikazivanjem životinjskih pratitelja kao "drugoga", te korištenjem životinjskih preobrazbi u svrhu moralne transformacije ljudskih likova.

${ }^{4}$ lako bi se iz ovoga moglo zaključiti da Disneyjevi filmovi promoviraju prava životinja, Patrick Murphy (1995) smatra da tomu ipak nije tako. Naime, kako navodi autor, likovi koji se loše odnose prema životinjama djeluju u izolaciji i njihovi se postupci ne prikazuju u širem kontekstu lova, ubijanja životinja radi krzna i slično, već su predstavljeni kao karakterne mane pojedinaca. Cruellina ljubav prema krznu (101 dalmatinac), primjerice, simptom je "njenog osobnog ekscesa i agresije, a ne klasnog ili kulturnog problema" (Murphy 1995: 129). 


\section{IMPERATIV DOMESTIKACIJE}

Eleanor Byrne i Martin McQuillan (1999) u domestikaciji prepoznaju jednu od dominantnih tema u Disneyjevim filmovima: bilo da se radi o djevojkama koje preuzimaju brigu nad kućanstvom ili mladim lavovima koji uče o važnosti zauzimanja dodijeljene im uloge u "krugu života", civiliziranje i pronalaženje vlastitog mjesta pod suncem imperativ su za Disneyjeve likove, kako ljudske tako i životinjske. U slučaju životinjskih likova, spomenuta se tema često manifestira kroz njihovo prepoznavanje ljudske nadređenosti i izražavanje želje za pripadanjem čovjeku, čime se dodatno potvrđuje antropocentrični pogled na svijet koji, kako ističe Murphy, negira postojanje divlje prirode (1995: 125). Ovaj stav možda je najeksplicitnije izražen u filmu Lilo i Stitch, u kojem izvanzemaljac Stitch (za kojeg djevojčica Lilo misli da je pas) mora odbaciti svoje urođene destruktivne impulse (divlju prirodu o kojoj piše Murphy) i usvojiti određene društvene norme kako bi mogao postati dio ljudske zajednice. Ta vrsta "valorizacije ljudske civilizacije kao vrhovnog standarda za sve: kako pse, tako i izvanzemaljce” (Leventi-Perez 2011: 74), otkriva antropocentrični nazor filma.

Nužnost domestikacije prepoznaju, dakle, i same životinje, koje ljudsku dominaciju prihvaćaju kao nešto prirodno, pretpostavljajući ljudsko društvo i sustave vrijednosti onim životinjskim. lako isprva uživa u društvu drugih četveronožaca, mačić Oliver (Oliver i kompanija) na koncu ipak odabire život kućnog ljubimca djevojčice Jenny. Osjećajna spona vlasnika i kućnog ljubimca u središtu je animiranog filma Grom, u kojem eponimski pas putuje diljem Sjedinjenih Američkih Država ne bi li se vratio svojoj “osobi”, djevojčici Penny. Pritom će uvjeriti i napuštenu mačku da životinjama ipak nije mjesto na ulicama velegrada, već u naručju njihovih vlasnika. U Dami i Skitnici psi s ogrlicama ponosno pokazuju svoje "značke povjerenja i ugleda", dok bi lutalice "dale stražnju lijevu nogu" da mogu nekome pripadati, potvrđujući time ideju da svaki pas želi pripadati čovjeku. Čak i Skitnica, kojem je pomisao na "život na uzici" isprva odbojna, ovisi o bečkim odrescima obitelji Schultz i mesnim okruglicama iz Tonyjeva restorana. Zagovornik slobodnog i samostalnog života, Skitnica će se do kraja filma ipak "civilizirati” prihvaćanjem višestruke uloge kućnog ljubimca, "supruga" i oca. Sličnu preobrazbu proživljava i ulični mačak Thomas O’Malley (Mačke iz visokog društva) koji na kraju filma lutalački život zamjenjuje obiteljskom i kućnom idilom.

Sveprisutnost i važnost domesticiranih životinja - napose kućnih ljubimaca - razvidna je i u filmovima sa životinjskim protagonistima, koji često i sami imaju neku vrstu ljubimca (npr. ljubimica štakora Ratigana, mačka Felicia [Miš veliki detektiv]). Nadalje, brojne divlje i druge životinje koje nisu tradicionalno kućni ljubimci često se prikazuju takvima, nerijetko poprimajući osobine najomiljenijeg Disneyjeva kućnog ljubimca, psa. Primjerice, dinosaur Earl (za razliku od svojih "vlasnica”, lišen sposobnosti govora) isplažena jezika u stopu slijedi Eemu i Baylene poput vjernog psića (Dinosaur). Konji Achilles (Zvonar crkve Notre Dame) i Maximus (Vrlo zapetljana priča) te sob Sven (Snježno kraljevstvo, Snježno kraljevstvo 2) također nalikuju psima: osim što plaze jezik (Sven), mašu repom i njuše tragove (Maximus), 
dresirani su poput pasa (Achilles i Maximus, primjerice, sjedaju na zapovijed), a njihovi vlasnici razgovaraju s njima, ponekad i odgovarajući u njihovo ime (Kristoff i sob Sven). ${ }^{5}$

\section{ŽIVOTINJSKO KAO "DRUGO"}

Dominantan nazor da je ljudsko prirodno nadređeno životinjskom vidljiv je i u slučajevima preobrazbi ljudskih likova u životinjske. lako se možda doimaju kao idealna prilika za stjecanje novih iskustava i razvijanje većeg senzibiliteta za životinjsko carstvo, tim je preobrazbama cilj preobraženike učiniti boljim ljudima, čime se životinjsko iskustvo stavlja u službu razvoja i poboljšanja ljudskoga. Sama preobrazba u životinju uglavnom je negativno intonirana kao svojevrsno unižavanje preobraženika, koji time, kako primjećuje Oana Leventi-Perez, gubi svoj privilegiran (ljudski) status (2011: 104). Nadalje, preobrazba u životinju često je kazna za devijantno ponašanje (neposlušni dječaci u Pinokiju pretvaraju se u magarce), sebičnost, lakomislenost, razmaženost i neosjetljivost za druge (Ljepotica i zvijer, Careva nova ćud, Princeza i žabac), te ubojstvo životinje (Legenda o medvjedu). Unatoč inicijalno negativnim reakcijama preobraženika, koji žele što prije povratiti svoja prvobitna obličja, njihovo životinjsko iskustvo potiče razvoj pozitivnih ljudskih osobina: samoživi Kuzco postaje altruističan (Careva nova ćud), okrutni kraljević u liku zvijeri uči voljeti (Ljepotica i zvijer), a razmaženi Naveen odlučuje bezbrižan donjuanovski život zamijeniti onime obiteljskog i radnog čovjeka (Princeza i žabac). Preobrazbe, dakle, redovito imaju pozitivan učinak na ljudski lik i njegovu okolinu; međutim, Leventi-Perez napominje kako se taj učinak ne proteže na životinjski svijet koji preobraženi lik upoznaje. Drugim riječima, filmovi ne ostavljaju dojam da je iskustvo bivanja životinjom čovjeka naučilo išta o prirodi, već samo o njemu samome (ibid.: 106). Robin Murray i Joseph Heumann (2011) primjećuju tu tendenciju u velikom broju Disneyjevih filmova (kako animiranih tako i igranih), od Knjige o džungli do ranije spomenutog uratka Lilo i Stitch. Ono što im je svima zajedničko, zaključuju autori, prikaz je prirode kao sredstva očuvanja statusa quo i pripitomljavanja čovjekovih "divljih" impulsa (Murray i Heumann 2011: 140).

Isto vrijedi i za preobrazbe kojima nije cilj kazniti, već poučiti ljudski lik, što je slučaj u Maču u kamenu: pretvarajući sebe i svog štićenika Warta (budući kralj Arthur) u razne životinje, čarobnjak Merlin mladića ne želi upoznati sa životinjskim svijetom, već mu prenijeti životne lekcije koje će mu koristiti kad jednom zasjedne na prijestolje. Jedini izuzetak nalazimo u filmu Legenda o medvjedu: za kaznu što je ubio medvjedicu (koju krivi za smrt svoga brata) mladi Kenai pretvara se u medvjeda. Zahvaljujući novom pogledu na svijet, postupno razvija senzibilitet za prirodu i modificira vlastita uvjerenja (uviđa da medvjedi nisu bezosjećajni ubojice koji napadaju ljude bez ikakvog razloga). Kao i gore nabrojani

${ }^{5}$ Ovakvu vrstu komunikacije u sklopu koje ljudi ne samo da se obraćaju životinjama već im i stavljaju vlastite riječi u usta tretirajući ih kao "trbuhozborčeve lutke koje im naizgled odgovaraju", Marc Shell naročito povezuje s kućnim ljubimcima i njihovim vlasnicima (2004: 85). 
likovi, Kenai se zahvaljujući vremenu provedenom u životinjskoj koži mijenja nabolje, no za razliku od njih, na kraju filma odlučuje zadržati medvjeđi lik i popraviti štetu nanesenu životinjskom svijetu brigom o novostečenom "mlađem bratu".

U filmovima s ljudskim protagonistima životinjski likovi, koji se često javljaju u ulogama prijatelja i pomagača, nerijetko služe kao sredstvo karakterizacije i samorealizacije protagonista. Usamljenim, marginaliziranim i/ili izoliranim likovima poput Pepeljuge (Pepeljuga), Aurore (Uspavana ljepotica), Zlatokose (Vrlo zapetljana priča) ili Kristoffa (Snježno kraljevstvo) često su jedino društvo, naglašavajući time njihovu odsječenost od ljudske zajednice i omogućavajući im da, kroz razgovor s njima, otkrivaju vlastite želje i snove. Sami životinjski likovi pritom su često lišeni sposobnosti govora te nemaju drugih želja ili ambicija mimo prijateljstva i pomaganja ljudskom protagonistu. Radnju, dakle, pokreće i usmjerava ljudska, a ne životinjska djelatnost (usp. Ortiz Robles 2016: 21).

U ranijim Disneyjevim filmovima poput Snjeguljice, Pepeljuge i Uspavane ljepotice, Condis prepoznaje funkciju životinjskih pratitelja kao "drugoga" u odnosu na kojega se ljudske protagonistice definiraju i dokazuju vlastitu egzemplarnost, "pokazujući dobroćudnu superiornost nad njihovim životinjskim podanicima" (2015: 40). Nadalje, podređenost životinja vidljiva je i u činjenici da se njihovo služenje junakinjama (za koje obavljaju kućanske i druge poslove) nikada ne dovodi u pitanje, već je "kodirano kao prirodno i neizbježno. Njima je zadovoljstvo služiti" (ibid.: 42). ${ }^{6}$

Odnos ljudskih i životinjskih likova u Disneyjevim animiranim filmovima dodatno potvrđuje njihovu suštinsku antropocentričnost, prikazujući čovjeka kao nužno nadređenog životinji. Taj "prirodni” poredak prihvaćaju i same životinje, prihvaćajući ljudsko društvo i pripadanje čovjeku kao vrhunske vrijednosti. Osim toga, životinjski likovi redovito se definiraju kroz odnos s čovjekom, bilo da funkcioniraju kao njegovo zrcalo (filmovi sa zoomorfima) ili služe kao njegovi pomagači i ljubimci (usp. Stewart i Cole 2009: 459-460).

\section{ZAVRŠNA RAZMATRANJA}

Analiza prikaza životinjskih likova u dugometražnim animiranim filmovima Studija Walt Disney te njihova odnosa s ljudskim likovima upućuje na dominantno antropocentričnu perspektivu, prema kojoj je svijet životinja (dobrovoljno) podređen onom ljudskom. Status ljudskog kao vrhunske vrijednosti očituje se u prvom redu kroz naglašenu antropomorfizaciju životinjskih likova te njihovu težnju da pripadaju i pomažu čovjeku. Pozitivno vrednovanje i važnost za filmsku priču veći su u slučaju životinjskih likova u čijim je prikazima prisutan veći stupanj antropomorfizacije (antropomorfi, zoomorfi). Nasuprot tomu, likovi

\footnotetext{
${ }^{6}$ Murray i Heumann (2011) nude drugačije čitanje odnosa između životinja i ranih Disneyjevih junakinja, ističući da se radi o međuovisnosti u kojoj obje strane profitiraju. Primjerice, miševi koji pomažu Pepeljugi šivajući joj haljinu i donoseći joj ključ kad je zaključana na tavanu od nje dobivaju hranu i zaštitu, tvoreći na taj načinu međuovisnu, "biotičku zajednicu” (Murray i Heumann 2011: 68).
} 
nižeg stupnja antropomorfizacije ("realistične" životinje) - naročito oni kojima nije pridana sposobnost govora - često imaju manje istaknute (pozadinske) uloge ili su prikazani u negativnom svjetlu. Identifikacija publike s likovima u tom se smislu temelji na njihovim ljudskim, a ne urođenim životinjskim osobinama, tj. na njihovoj bliskosti i sličnosti čovjeku.

Životinjski likovi u analiziranim filmovima u prvom se redu definiraju kroz njihov odnos s čovjekom, tj. njihovu sličnost (osobine, ponašanje, međusobni odnosi, društvena uređenja i sl.), iskustvenu bliskost i korisnost čovjeku (pratitelji, pomagači). lako filmovi u pravilu pozitivno vrednuju prijateljstvo čovjeka i životinje, a nasilje nad životinjama prikazuju u negativnom svjetlu, ta se spona prikazuje kao vrlo poželjna za životinjske likove, kojima je nerijetko krajnji cilj pripadati i pomagati čovjeku. Uz malobrojne izuzetke (npr. Legenda o medvjedu), životinjski i ljudski svijet jasno su razdvojeni, a njihova interakcija poglavito je u službi čovjeka. Tako i preobrazbe ljudskog u životinjski lik ne služe kako bi preobraženika upoznale sa životinjskim svijetom, već kako bi mu pomogle da postane boljim čovjekom.

Ne pretendirajući na iscrpnost, ovdje predstavljeno istraživanje neizbježno je zaobišlo niz zanimljivih i poticajnih tema vezanih za životinjske likove u Disneyjevim filmovima, koje bi mogle poslužiti kao poticaj za buduća istraživanja. S obzirom na zanimljive rezultate koje su polučile dosadašnje analize zoonima i zoonimske frazeologije (npr. Barčot 2017; Vidović Bolt 2014), uporaba jezika nadaje se kao jedno od mogućih područja daljnjih istraživanja, naročito imamo li na umu činjenicu da se ljudski likovi u Disneyjevim filmovima često međusobno nazivaju (pogrdnim) životinjskim nazivima (u Maču u kamenu Merlin Arthura naziva "malim skakavcem", Petar Pan vrijeđa Kapetana Kuku nazivajući ga bakalarom [Petar Pan], Aladin je među gradskom stražom poznat kao "ulični štakor" [Aladin] itd.). S tim u vezi je i proučavanje prijevoda i sinkronizacije filmova na hrvatski jezik (usp. Žanić 2009). Zanimljive rezultate zacijelo bi polučile i analize životinjskih likova na razini pojedinih filmova, kao i usporedbe prikaza i uloga pojedinih vrsta u različitim filmovima (npr. mačke u Disneyjevim animiranim filmovima i slično).

\section{LITERATURA I IZVORI}

Anderson, Marla V. i Antonia J. Z. Henderson. 2005. "Pernicious Portrayals. The Impact of Children's Attachment to Animals of Fiction on Animals of Fact". Society \& Animals 13/4: 297-314. https:// doi.org/10.1163/156853005774653645

Baker, Steve. 2001. Picturing the Beast. Animals, Identity and Representation. Urbana, Chicago: University of Illinois Press.

Barčot, Branka. 2017. Lingvokulturologija i zoonimska frazeologija. Zagreb: Hrvatska sveučilišna naklada.

Beaudine, Gregory, Oyemolade Osibodu i Aliya Beavers. 2017. "Disney's Metaphorical Exploration of Racism and Stereotypes. A Review of Zootopia". Comparative Education Review 61/1: 227-234. https://doi.org/10.1086/690061

Brode, Douglas. 2005. Multiculturalism and the Mouse. Race and Sex in Disney Entertainment. Austin: University of Texas Press. 
Burt, Jonathan. 2002. Animals in Film. London: Reaktion Books Ltd.

Byrne, Eleanor i Martin McQuillan. 1999. Deconstructing Disney. London, Sterling: Pluto Press.

Condis, Megan. 2015. "She Was a Beautiful Girl and All the Animals Loved Her. Race, the Disney Princesses, and Their Animal Friends". Gender Forum 55: 39-54.

Detela, Jurij. 1977. "Poezija znanega liberalca in podoficirja Jurija Detele na témo: Čebelarstvo in prevzgoja bobrov na Slovaškem in pa čebelarstvo in prevzgoja bobrov pri nas na Slovenskem z ozirom". Problemi. Literatura 16(3-4)/170-171: 521-524.

Finch, Christopher. 2011. The Art of Walt Disney. From Mickey Mouse to the Magic Kingdom and Beyond. New York: Abrams.

Giroux, Henry A. i Grace Pollock. 2010. The Mouse That Roared. Disney and the End of Innocence. Prošireno izdanje. Lanham: Rowman \& Littlefield.

Golež Kaučič, Marjetka. 2018. “Pes v filmu. Od resničnosti v fikcijo”. Traditiones 4/2:117-30. Dostupno na: https://ojs.zrc-sazu.si/traditiones/article/view/7177 (pristup 10. 9. 2020.). https://doi.org/10.3986/ Traditio2018470207

Grant, John. 1998. Encyclopedia of Walt Disney's Animated Characters. New York: Hyperion.

Hameršak, Marijana A. 2015. “Središte ruba. Životinje i dječja književnost”. Detinjstvo 41/2: 29-39.

Harries, Elizabeth Wanning. 2003. Twice Upon a Time. Women Writers and the History of the Fairy Tale. New Jersey: Princeton University Press.

Holliss, Richard i Brian Sibley. 1986. Walt Disney's Mickey Mouse. His Life and Times. New York: Harper \& Row.

Kashani, Tony. 2010. "Hollywood and Nonhuman Animals. Problematic Ethics of Corporate Cinema". U Hollywood's Exploited. Public Pedagogy, Corporate Movies, and Cultural Crisis. Benjamin Frymer, Tony Kashani, Anthony J. Nocella II i Rich Van Heertum, ur. New York: Palgrave Macmillan, 219-234. https://doi.org/10.1057/9780230117426_14

LaMarre, Thomas. 2008. "Speciesism, Part I. Translating Races into Animals in Wartime Animation". Mechademia 3/1: 75-95. https://doi.org/10.1353/mec.0.0069

Leventi-Perez, Oana. 2011. Disney's Portrayal of Nonhuman Animals in Animated Films Between 2000 and 2010. Neobjavljen magistarski rad. Georgia: Georgia State University. Dostupno na: http://scholarworks.gsu.edu/cgi/viewcontent.cgi?article=1084\&context=communication_theses (pristup 18. 2. 2020.).

Maltin, Leonard. 2000. The Disney Films. New York: Disney Editions.

Marjanić, Suzana i Antonija Zaradija Kiš, ur. 2007. Kulturni bestijarij. Zagreb: Institut za etnologiju i folkloristiku, Hrvatska sveučilišna naklada.

Marjanić, Suzana i Antonija Zaradija Kiš, ur. 2012. Književna životinja. Kulturni bestijarij, 2. Zagreb: Institut za etnologiju i folkloristiku, Hrvatska sveučilišna naklada.

Murphy, Patrick D. 1995. “The Whole Wide World Was Scrubbed Clean'. The Androcentric Animation of Denatured Disney". U From Mouse to Mermaid. The Politics of Film, Gender, and Culture. Elizabeth Bell, Lynda Haas i Laura Sells, ur. Bloomington: Indiana University Press, 125-136.

Murray, Robin L. i Joseph K. Heumann. 2011. That's All Folks? Ecocricial Readings of American Animated Features. Lincoln, London: University of Nebraska Press. https://doi.org/10.2307/j.ctt1df4gsn

Ortiz Robles, Mario. 2016. Literature and Animal Studies. London, New York: Routledge. https://doi. org/10.4324/9781315880389

Riffel, Casey. 2012. "Dissecting Bambi. Multiplanar Photography, the Cel Technique, and the Flowering of Full Animation". The Velvet Light Trap 69/1: 3-16. https://doi.org/10.1353/vlt.2012.0007

Sax, Boria. 2013. Imaginary Animals. The Monstrous, the Wondrous and the Human. London: Reaktion Books. 
Shell, Marc. 2004. "Animals That Talk; Or, Stutter". differences. A Journal of Feminist Cultural Studies 15/1: 84-107. https://doi.org/10.1215/10407391-15-1-84

Siegel, Sarita. 2005. "Reflections on Anthropomorphism in The Disenchanted Forest". U Thinking with Animals. New Perspectives on Anthropomorphism. Lorraine Daston i Gregg Mitman, ur. New York: Columbia University Press, 196-222.

Smith, Dave. 1996. Disney A to Z. The Official Encyclopedia. New York: Hiperion.

Stewart, Kate i Matthew Cole. 2009. "The Conceptual Separation of Food and Animals in Childhood". Food, Culture \& Society 12/4: 457-476. https://doi.org/10.2752/175174409X456746

Šešo, Luka. 2007. “Vjerovanja u bića koja se pretvaraju u životinje”. U Kulturni bestijarij. Suzana Marjanić i Antonija Zaradija Kiš, ur. Zagreb: Institut za etnologiju i folkloristiku, Hrvatska sveučilišna naklada, 253-275.

Tatar, Maria. 2003. The Hard Facts of the Grimms' Fairy Tales. Princeton, Oxford: Princeton University Press.

Tobias, Ronald. 2011. Film and the American Moral Vision of Nature. Theodore Roosevelt to Walt Disney. East Lansing: Michigan State University Press.

Vidović Bolt, Ivana. 2007. "Metaforika zoonima u hrvatskoj frazeologiji”. U Kulturni bestijarij. Suzana Marjanić i Antonija Zaradija Kiš, ur. Zagreb: Institut za etnologiju i folkloristiku, Hrvatska sveučilišna naklada, 403-424.

Vidović Bolt, Ivana, ur. 2014. Životinje u frazeološkom ruhu. Zagreb: FF press.

Visković, Nikola. 1996. Životinja i čovjek. Prilog kulturnoj zoologiji. Split: Književni krug.

Visković, Nikola. 1998. "Šest načina odnosa prema životinji”. U Kulturna animalistika. Zbornik radova sa znanstvenog skupa održanog 29. rujna 1997. godine u Splitu. Nenad Cambi i Nikola Visković, ur. Split: Književni krug, 11-15.

Whitley, David. 2008. The Idea of Nature in Disney Animation. Aldershot: Ashgate. https://doi. org/10.4324/9786611208011

Zipes, Jack. 2006. Fairy Tales and the Art of Subversion. The Classical Genre for Children and the Process of Civilization. New York: Routledge.

Žanić, Ivo. 2009. Kako bi trebali govoriti hrvatski magarci? O sociolingvistici animiranih filmova. Zagreb: Algoritam.

\section{Filmografija}

101 dalmatinac (One Hundred and One Dalmatians), redatelji Clyde Geronimi, Hamilton Luske i Wolfgang Reitherman, 1961.

Aladin (Aladdin), redatelji Ron Clements i John Musker, 1992.

Bambi, redatelj David D. Hand, 1942.

Careva nova ćud (The Emperor's New Groove), redatelj Mark Dindal, 2000.

Crni kotao (The Black Cauldron), redatelji Ted Berman i Richard Rich, 1985.

Dama i Skitnica (Lady and the Tramp), redatelji Clyde Geronimi, Wilfred Jackson i Hamilton Luske, 1955.

Dinosaur, redatelji Eric Leighton i Ralph Zondag, 2000.

Grom (Bolt), redatelji Byron Howard i Chris Williams, 2008.

Herkul (Hercules), redatelji Ron Clements i John Musker, 1997.

Knjiga o džungli (The Jungle Book), redatelj Wolfgang Reitherman, 1967. 
Kralj lavova (The Lion King), redatelji Roger Allers i Rob Minkoff, 1994.

Legenda o medvjedu (Brother Bear), redatelji Aaron Blaise i Robert Walker, 2003.

Lilo i Stitch (Lilo \& Stitch), redatelji Dean DeBlois i Chris Sanders, 2002.

Lisica i pas (The Fox and the Hound), redatelji Ted Berman, Richard Rich i Art Stevens, 1981.

Ljepotica i zvijer (Beauty and the Beast), redatelji Gary Trousdale i Kirk Wise, 1991.

Mač u kamenu (The Sword in the Stone), redatelj Wolfgang Reitherman, 1963.

Mačke iz visokog društva (The Aristocats), redatelj Wolfgang Reitherman, 1970.

Mala sirena (The Little Mermaid), redatelji Howard Ashman i John Musker, 1989.

Miš veliki detektiv (The Great Mouse Detective), redatelji Ron Clements, Burny Mattinson, David Michener i John Musker, 1986.

Oliver i kompanija (Oliver \& Company), redatelj George Scribner, 1988.

Pepeljuga (Cinderella), redatelji Clyde Geronimi, Wilfred Jackson i Hamilton Luske, 1950.

Petar Pan (Peter Pan), redatelji Clyde Geronimi, Wilfred Jackson i Hamilton Luske, 1953.

Pinokio (Pinocchio), redatelji Hamilton Luske i Ben Sharpsteen, 1940.

Planet s blagom (Treasure Planet), redatelji Ron Clements i John Musker, 2002.

Pocahontas, redatelji Mike Gabriel i Eric Goldber, 1995.

Princeza i žabac (The Princess and the Frog), redatelji Ron Clements i John Musker, 2009.

Robin Hood, redatelj Wolfgang Reitherman, 1973.

Slonić Dumbo (Dumbo), redatelj Ben Sharpsteen, 1941.

Snjeguljica i sedam patuljaka (Snow White and the Seven Dwarfs), redatelj David Hand, 1937.

Snježno kraljevstvo (Frozen), redatelji Chris Buck i Jennifer Lee, 2013.

Snježno kraljevstvo 2 (Frozen 2), redatelji Jennifer Lee i Chris Buck, 2019.

Spasioci (The Rescuers), redatelji John Lounsbery, Wolfgang Reitherman i Art Stevens, 1977.

Spasioci u Australiji (The Rescuers Down Under), redatelji Hendel Butoy i Mike Gabriel, 1990.

Šala i mašta (Fun and Fancy Free), redatelji Jack Kinney, Hamilton Luske, William Morgan i Bill Roberts, 1947.

Tarzan, redatelji Chris Buck i Kevin Lima, 1999.

Uspavana ljepotica (Sleeping Beauty), redatelj Clyde Geronimi, 1959.

Vrlo zapetljana priča (Tangled), redatelji Nathan Greno i Byron Howard, 2010.

Zootropola (Zootopia), redatelji Byron Howard i Rich Moore, 2016.

Zvonar crkve Notre Dame (The Hunchback of Notre Dame), redatelji Gary Trousdale i Kirk Wise, 1996.

Žuta minuta (Chicken Little), redatelj Mark Dindal, 2005.

\section{DISNEY'S ANIMATED ANTHROPOMORPHS}

Playful anthropomorphic animals are probably one of the most recognizable traits of the animated features produced by the Walt Disney Animation Studio. In addition to its eponymous heroes and heroine, Snow White and the Seven Dwarfs (1937), Disney's first full-length animated feature, included a group of benevolent forest animals which helped the heroine by protecting her and doing household chores. Given the immense 
success of Snow White, the motif of animal helpers/companions was used in the films that followed, eventually becoming a permanent feature of Disney's repertoire. This paper focuses on animal (i.e. non-human animal) characters in Disney's full-length animated feature films. The research corpus encompasses 48 films released between 1937 and 2019. Situated within the frameworks of Disney studies and cultural animal studies, the paper analyses the representation of animal characters, especially their anthropomorphisation and the way their protagonist/antagonist status is visually coded, as well as the relationship between human and animal characters. The research results point to a predominantly anthropocentric perspective of the analysed films.

Keywords: animated film, anthropomorphism, cultural animal studies, Walt Disney Animation Studio, animals 